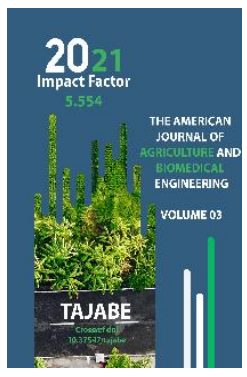

Journal Website: http://theamericanjour nals.com/index.php/taj abe

Copyright: Original content from this work may be used under the terms of the creative commons attributes 4.0 licence.

\section{Importance Of Seeded Fruits Storage}

\author{
Khurmatov Y.E. \\ Senior Teacher, Andijan Institute Of Agriculture And Agrotechnologies, Uzbekistan \\ Kakhkhorova S.A. \\ Student, Andijan Institute Of Agriculture And Agrotechnologies, Uzbekistan \\ Nazirova U.A. \\ Student, Andijan Institute Of Agriculture And Agrotechnologies, Uzbekistan \\ Tursumatov M.S. \\ Student, Andijan Institute Of Agriculture And Agrotechnologies, Uzbekistan \\ Abdulkhamidova M.A. \\ Students, Andijan Institute Of Agriculture And Agrotechnologies, Uzbekistan
}

\title{
ABSTRACT
}

Seeded fruits are distinguished by their healing properties, rich in nutrients and vitamins. These fruit storage methods are of interest to everyone. In order to provide the population with fruits throughout the year, it is really useful to know how to store seeded fruits, the main task of food storage is to preserve their physicochemical composition, i.e. appearance, color, taste, as well as nutritional value and other properties.

\section{KEYWORDS}

Seed varieties, natural storage methods, technologies, plastic containers, Japanese containers, storage properties, quality indicators.

\section{INTRODUCTION}

In recent years, in our country, much attention has been paid to the cultivation, storage and high-quality delivery of agricultural products to consumers.Growing and storing agricultural products at the demand level increases not only the size of the domestic market, but also the export market.he role of horticulture and viticulture is especially important. However, therearenoshortcomingsinthisdirection.From the very beginning of the consumption of seeds of fruit products, they were engaged in its storage and processing. One of the human needs is to store and process a product without destroying it or reducing its quality.Fruits and grape products are known to be grown during certain seasons of the year. For this reason, it is impossible to solve the problem of providing population with a variety 
The American Journal of Agriculture and Boimedical Engineering (ISSN - 2689-1018)

of products throughout the year without organizing their long-term storage and processing.

If the collection, transportation, processing and storage of fruits and grape products will be organized scientifically, on the basis of advances in science and technology and excellence, the amount of product waste will be greatly reduced.

\section{RESEARCH METHODS AND MATERIALS}

Apple fruit conservation

The storage stability of apples is determined by their ripening properties.

Early ripe apple varieties can be stored for a short time, and late ones - 7-8 months.

Apples are usually placed in storage boxes.

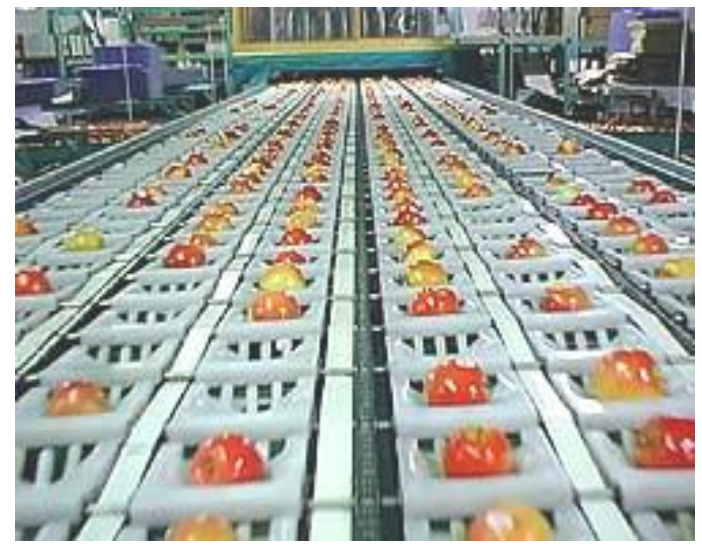

this case, the apple will be better preserved if it is wrapped in paper.

When placing apples in crates, you can also place a piece of paper or scrap in between them.
The boxes are placed in the warehouse 25-30 $\mathrm{cm}$ from the wall, leaving a two-meter path between the boxes.

There will be 7-8 boxes on the board. There should be 50-60 centimeters of space between the attachment and the ceiling of the warehouse.

When storing apples, it is desirable that the relative humidity is $85-95 \%$.

The cooling of the warehouse is achieved by vigorous stirring until the air reaches the storage temperature.

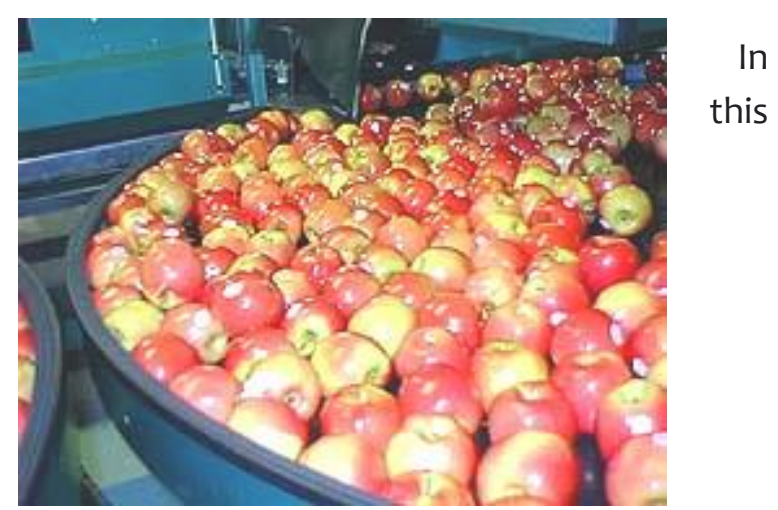

case, it is recommended that the air flow rate between the trays is $0.2-0.3$ meters per second.

Before storage, apples are stored in special compartments. Before storing apples toEvery day $10-15 \%$ of the capacity of the fruit storage compartment is filled with apples.

The block will be completely filled in 7-10 days. The air in the compartments is gradually cooled down to $+4+6 \mathrm{oC}$. It is then left at the temperature required for the variety. 
locks of the highest and first grade are stored

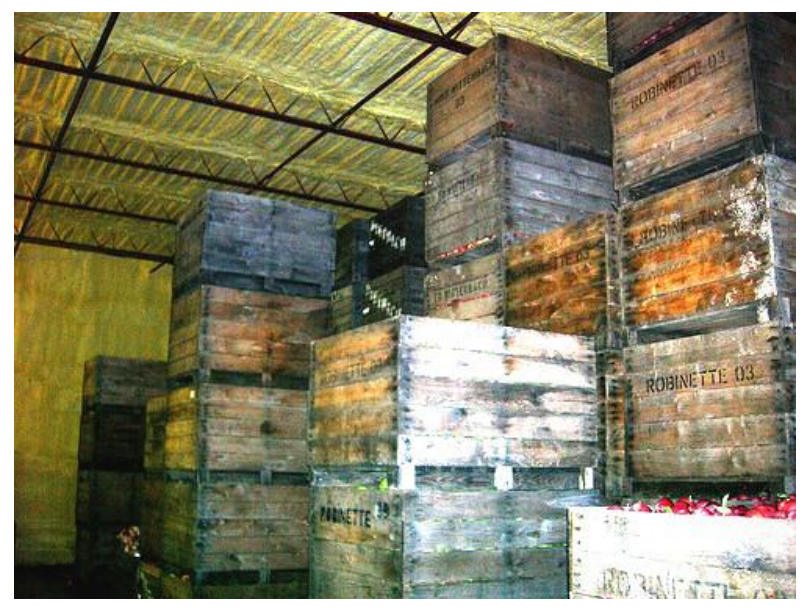

for a long time, apples of the second and third grades - 2-3 months

They are stored in boxes, cardboard boxes and containers. Storing fruit in containers efficient use of the usable volume of each cubic meter of the warehouse provides. At the same time, when storing the fruit in boxes with a useful volume of $1 \mathrm{~m} 3$, its density is 250$300 \mathrm{~kg}$, in containers - $400 \mathrm{~kg}$.

When storing apples, the method of storing them in plastic wrap is also used.

In this case, plastic bags with a capacity of 1-3 $\mathrm{kg}$ are used. In such packages for 1.5-2 months the amount of oxygen reaches $14-16 \%$, and carbon dioxide $-5-7 \%$.

\section{RESEARCH RESULTS AND DISCUSSION}

Pear fruit conservation.

Resistant pear varieties can be stored for 4-5 months, and autumn ones - 1.5-2 months.

Pears tend to ripen faster than apples, so care must be taken when cutting and placing them in crates.
Pears are usually cut before ripening and placed in clean and dry boxes. Eatpaperundertheboxes

Bend the other end of the paper over the pear.

You can also stagger the pear and sprinkle it with crumbs between the rows.

When storing pears, temperatures between 0 and $+2{ }^{\circ} \mathrm{C}$ are preferred.

Often at this temperature, the fruits of very late varieties ripen very slowly and remain firm without losing color until the end of storage. Before shipment, such pears must be stored and kept at a temperature of $15-20^{\circ} \mathrm{C}$ for 4-7 days.

He relative humidity in the warehouse should be $85-90 \%$.

It should be noted that frequent temperature changes should not be allowed.

Air in the warehouse, otherwise the fruits can ripen quickly, such pears cannot be stored for a long time.

\section{Storingbexifruits.}

Bexia is also placed in storage boxes. If placed in boxes, you can also place a sheet of paper or scrap paper between boxes. Relativehumidity $85-90 \%$, temperature $0+$ $40 C$.

If all the necessary standards are observed when storing beksi fruits, it will be possible to store the fruits for 5-6 months. Measures have been taken to heat the premises. 
Shuningdek, toforalardaxamsuvlarқy̆yilgan. Bu choraxavoisib, namlikkamayibketgankunlarikurilgan.

However, on continuous foggy and continuous rainy days, the limestone was left untouched in order to reduce the amount of moisture.

Limestone absorbs excess moisture, melts and crumbles.

\section{RESEARCH RESULTS AND DISCUSSION}

\section{Last method used:}

Thus, the grapes are not cut from the vine.

Usually the vineyard is surrounded by a wall around the perimeter, and a door (hole) is placed in the middle of the wall, allowing air to enter and circulate.

On hot days, the holes are open for two days, and on cold days they are closed for two nights.

For this method, the sieve is usually pulled along the wall.

When the air temperature begins to drop below $+5^{\circ} \mathrm{C}$, a plastic wrap is tightened on top of the bag.

As the weather cools down, hay and vegetable gardens are left on top of the film.

It also maintains an overall temperature of about $0^{\circ} \mathrm{C}$ by installing light bulbs and heaters in some parts of the vineyard.

In this case, of course, the grapes are stored in the bunch for a long time, but the weariness of the grape rust leads to the failure of the next year's harvest.

The Mirshaks seem to have found a way to do just that.

To do this, the heads of cabbage are completely cut off from the grapes on one of the three fruitful branches and left for the next year, and in the spring the tired branches are cut off.

\section{The currently popular method is:}

Newspapers are choked with small wooden boxes on which the heads of grapes are tightly stacked.

For storage, of course, large grains and fresh and well-ripened heads of grapes are select

When they are harvested tightly, the moisture in the grapes lasts for a long time.

This also leads to long-term and high-quality maintenance of the initial state of weight.

The harvested crop is usually harvested in the autumn months, when the temperature drops below $+20^{\circ} \mathrm{C}$.

In early August, when the grapes intended for winter storage begin to ripen, that is, in common parlance, when water begins to flow, the top of each of them is wrapped in a paper tube.

Thus, they take care of the preservation of the natural pollen of the fruit, taking care of the rains and morning dew. 
Its natural pollen, that is, its unique natural coating, ensures a long and high-quality preservation of the grapes.

\section{CONCLUSION}

In conclusion, we can say that the care of the seed crop is correct in the process of seed ripening.

One of the important tasks of the organization is to study the processes of natural decline in the annual provision of the population with the safety of cultivated seeds.

Control of active water In our opinion, the shelf life of products can be determined by determining the amount of active moisture in them.

\section{REFERENCES}

1. Ўзбекистон Республикаси Президенти Ш. Мирзиёевнинг 2019 йил 11 декабрдаги Пқ - 4549-сонли “Мева-сабзавотчилик ва узумчилик тармоғини янада ривожлантириш, сохада қўшилган қиймат занжирини яратишга доир қўшимча чора-тадбирлар" тўғрисидаги қарори. 11.12.2019 йил - Лех.уз

2. Мирзаев М.M и др. Ампелография Узбекистана. Ташкент: «Узбекистан», 1984

3. Серпуховитина К.А., Худавердов Э.Н. Проблема воспроизводства плодородия почв виноградников в обозримом периоде ХХИ столетия. Материалы Между-народной научно - практической конференции. Садовод г.
4. Sharipovich, A. A., Sheralievich, Y. N., Botirovna, S. M., \&Mukhammadovna, E. J. (2020). Study of methods for identification and storage of morphological features of grapes grown in the conditions of Fergana Region. The American Journal of Agriculture and Biomedical Engineering, 2(07), 20-24.

5. Xatamova, X. K., Yuldasheva, K. T., Soliyeva, M. B., Kimsanova, X. A., \&Juraboyeva, S. M. (2021). Methods of preserving subtropical fruits. Asian Journal of Multidimensional Research (AJMR), 10(1), 109-115.

6. ВАХОБОВ, А., СОЛИЕВА, М., \& XАТАMOBA, $\quad$. COPTA КРАСНОКОЧАННОЙ КАПУСТЫ ДЛЯ ПОВТОРНОЙ КУЛЬТУРЫ.ИРРИГАЦИЯМЕЛИОРАЦИЯ, 57.

7. Alisher, V., Komiljonovna, K. H., Botirovna, S. M., \&Yulbarsovna, D. S. (2020). БАМИЯШИФОБАХШЎСИМЛИКВАУНИЕТИШТИРИ ШТЕХНОЛОГИЯСИ. PalArch'sJournalofArch aeologyofEgypt/Egyptology, 17(6), 34793482.

8. Soliyeva, M. B., Sh, T. J., \&Asronov, E. K. (2021). To Learn Of Biological And Productive Indicators Of Imported Mulberry Silkworm Breeds. The American Journal of Applied sciences, 3(04), 131-137.

9. Asronov, E. K., \&Soliyeva, M. B. (2020). The importance of feeding silkworms under polyethylene. ACADEMICIA: An International Multidisciplinary Research Journal, 10(10), 1169-1174.

10. Асронов, Э. К., \&Солиева, М. Б. (2020). ВЛИЯНИЕ ИЗМЕНЕНИЯ ТЕМПЕРАТУРЫ НА ПРОДУКТИВНОСТЬ И КАЧЕСТВО КОКОНОВ ВО ВРЕМЯ КОРМЛЕНИЯ ТУТОВОГО ШЕЛКОПРЯДА. Экономика И социум, (12-1), 388-391. 
11. Soliyeva, M. B., Yuldasheva, K. T., Xatamova, X. K., Kimsanova, X. A., \&lsroilova, S. S. (2021). The effect of shelf life of live cocoons on their temperature and quality. Asian Journal of Multidimensional Research (AJMR), 10(3), 254-260

12. Туйчиев, Ж. Ш., Убайдуллаев, С. Ш., Турдиева, Ф. Т., \&Солиева, М. Б. (2015). ИЗМЕНЕНИЕ ДОЛИ ДЕФЕКТНЫХ КОКОНОВ В ЗАВИСИМОСТИ ОТ СРОКОВ ПОСТУПЛЕНИЯ НА ЗАВОД. СовременнЫе тенденции развития науки $и$ технологий, (4-2), 78-81.

13. Туйчиев, Ж. Ш., Мирзаев, Р. О., Солиева, М., \& Гафурова, Ю. К. (2016). ЗАВИСИМОСТЬ КАЧЕСТВА КОКОНОВ ПЕРВИЧНОГО ПОКОЛЕНИЯ ОТ КОЛИЧЕСТВА ФОРМ ИЗМЕНЕННЫХ ИЗ ПАРТИИ ПЛЕМЕННЫХ. СОвреМеннЫе тенденции развития науки и технологий, 124.

14. Yuldasheva, K. T., Soliyeva, M. B., Daminov, X. E., Botirov, S. T., \&Mamadjanova, G. S. (2021). The process of growth of vegetative organs of olive seedlings in protected areas during the development phase. ASIAN JOURNAL OF MULTIDIMENSIONAL RESEARCH, 10(4), 287-293.

15. Sokhibova, N. S., Nazirova, M. I. K., \&Botirovna, S. M. (2020). INFLUENCE OF REARING SILK WORMS WITH HIGH PRODUCTIVE MULBERRY LEAVES ON THE BIOLOGICAL INDICATORS OF SILK GLAND AND RAW SILK EFFECTIVENESS. Life Sciences and Agriculture, (2).

16. Yuldasheva, K. T., Soliyeva, M. B., Kimsanova, X. A., Arabboev, A. A., \&Kayumova, S. A. (2021). Evaluation of winter frost resistance of cultivated varieties of olives. ACADEMICIA: AN
INTERNATIONAL MULTIDISCIPLINARY

RESEARCH JOURNAL, 11(2), 627-632.

17. Yuldasheva, K. T., Soliyeva, M. B., Xatamova, X. K., \&Kimsanova, X. A. (2020). Effect of arbuscular mycorrhiza on micro propagated olive. ACADEMICIA: AN INTERNATIONAL MULTIDISCIPLINARY RESEARCH JOURNAL, 10(12), 1491-1498.

18. Асронов, Э. К., Салиева, М. Б., Салиев, С. А., \&Давлатов, Х. Р. (2018). ХРАНЕНИЕ ПЛОДООВОЩНОЙ ПРОДУКЦИИ. In Северный морской путь, водные и сухопутные транспортные коридоры как основа развития Сибири и Арктики в XXI веке (рр. 264-266).

19. Xatamova, X. K., Soliyeva, M. B., Kimsanova, X. A., Yunusov, O. B., \&Yuldashev, R. T. (2021). Methods Of Drying Subtropical Fruits And Their Importance For Human Health. The American Journal of Applied sciences, 3(05), 148-154.

20. Асранав, Э. К., Салиева, М., \&Алижанов, Ж. (2019). ЛЕЧЕБНЫЕ СВОЙСТВА ТУТОВНИКА. Академическая публицистика, (5), 24-28. 